\title{
COMPARATIVE FLORAL ANATOMY AND DEVELOPMENT IN NEOTROPICAL LAURACEAE
}

\author{
M. Graça Sajo, ${ }^{*}$ Pedro L. R. Moraes, ${ }^{*}$ Leandro C. S. Assis, $†$ and Paula J. Rudall ${ }^{1,}$ \\ *Instituto de Biociências, Universidade Estadual Paulista, Botânica, Rio Claro, CEP 13506-900, São Paulo, Brazil; †Instituto de Biociências, \\ Universidade Federal de Minas Gerais, Departamento de Botânica, Belo Horizonte, CEP 31270-901, Minas Gerais, \\ Brazil; and ¥Royal Botanic Gardens, Kew, Richmond, Surrey TW9 3AB, United Kingdom
}

Editor: Maria von Balthazar

\begin{abstract}
Premise of research. The pantropical magnoliid family Lauraceae has an extensive macrofossil record that dates back to the Early Cretaceous. However, flower anatomy among extant species is relatively poorly known. We investigate flower structure and development in six Neotropical genera to elucidate the homologies of the floral parts, especially the prominent appendages that occur on the filaments of the inner fertile stamen whorl in some species.

Methodology. We used SEM and LM to examine flower organization and development in 11 species of six genera (Aniba, Cryptocarya, Endlicheria, Licaria, Nectandra, Ocotea) and flower vasculature in two species (Cryptocarya moschata and Ocotea prolifera).

Pivotal results. All the flowers examined are typical of Lauraceae: they are very small and possess two whorls of tepals that are similarly vascularized, with three bundles each (resembling bracteopetals), multiple androecium whorls, and a single carpel. Variation exists in some characters, especially in the androecium. A fourth (innermost) androecial whorl is present as staminodia in some species. The prominent stamen appendages are highly vascularized.

Conclusions. The presence of three vascular bundles supplying both outer and inner tepals supports their potential homology as bracteotepals. Floral vasculature also indicates that the staminodia of the fourth androecial whorl are derived from stamens. A potential homology between the stamens and appendages remains debatable, because existing evidence is contradictory.
\end{abstract}

Keywords: bracteopetals, floral development, homology, stamen appendages, staminodes, vasculature.

\section{Introduction}

The pantropical magnoliid family Lauraceae (ca. 50 genera, 3000 species) belongs in the magnoliid order Laurales (seven families), in a clade together with Hernandiaceae and Monimiaceae (Renner 1999, 2004; Doyle and Endress 2000; Renner and Chanderbali 2000; Chanderbali et al. 2001). Although the magnoliids probably diverged at around the same time as the more species-rich monocot and eudicot clades, their macrofossil record is more extensive; Lauraceae flowers have a macrofossil record that dates back to the Early Cretaceous (e.g., Drinnan et al. 1990; Eklund and Kvacek 1998; Eklund 2000; von Balthazar et al. 2007; Atkinson et al. 2015).

Flowers of most extant Lauraceae possess two whorls of tepals (outer and inner tepals), three whorls of fertile stamens, sometimes an inner whorl of staminodia, and a pistil with a superior ovary. The anthers open by two or four valves; dehiscence is usually introrse in the two outer stamen whorls and extrorse in the third (innermost) whorl, where a pair of glands is located at the stamen base, a feature also seen in some Moni-

\footnotetext{
1 Author for correspondence; e-mail: p.rudall@kew.org. Manuscript received March 2016; revised manuscript received April 2016; electronically published June 29, 2016.
}

miaceae (Endress 1972; Endress and Hufford 1989). Even where sparse material is available, Lauraceae flowers are often relatively small $(<1 \mathrm{~cm}$ in diameter), and in many species they are covered with rigid hairs that make it difficult to process the samples for anatomical studies. Thus, floral anatomy and development are surprisingly poorly known in most species, with some exceptions (Reece 1939; Kasapligil 1951; Sastri 1952, 1958, 1965; Buzgo et al. 2007; Chanderbali et al. 2009).

In this article, we investigate the flower structure and development of 11 Neotropical species in six genera (table 1) and the anatomy and vasculature of two species (Ocotea prolifera and Cryptocarya moschata). Our primary goals are to elucidate the homologies of the floral parts to understand floral evolution within the family. We address several questions: (1) whether the tepals in Lauraceae represent modified bracts (bracteopetals), as suggested by other authors (e.g., Sastri 1965; reviewed in Ronse De Craene 2008; Warner et al. 2009), or stamens (androtepals; Chanderbali et al. 2006); (2) whether the prominent stamen appendages (nectaries) at the basis of the third androecial whorl represent glandular outgrowths or modified stamens (Buzgo et al. 2007); and (3) which are the homologies of the fourth (staminodial) androecial whorl and their glands. However, homology questions in Lauraceae are hindered by the currently limited understanding of phylogenetic 
Table 1

Plants Examined and Voucher Information

\begin{tabular}{|c|c|}
\hline Genus & Species and plants examined \\
\hline \multicolumn{2}{|l|}{ Cryptocarya group: } \\
\hline Cryptocarya R.Br. & Cryptocarya moschata Nees \& Mart. (HRCB: Moraes 3491) \\
\hline \multicolumn{2}{|c|}{ Ocotea group (core Lauraceae-Cinnamomeae): } \\
\hline Aniba Aubl. & Aniba firmula (Nees \& Mart.) Mez (SPF: Santos \& Marques 400) \\
\hline \multirow[t]{2}{*}{ Endlicheria Nees } & Endlicheria glomerata Mez (HRCB: Moraes 3497) \\
\hline & Endlicheria paniculata (Spreng.) J.F. Macbr. (SPF: Assis et al. 1242) \\
\hline Licaria Aubl. & Licaria aff. guianensis Aubl. (HRCB: Moraes \& Kamimura 3564) \\
\hline \multirow[t]{3}{*}{ Nectandra Rottb. } & Nectandra psammophila Nees \& Mart. (HRCB: Moraes \& Siqueira 3483) \\
\hline & Nectandra nitidula Nees \& Mart. (HRCB: Moraes 3499) \\
\hline & Nectandra oppositifolia Nees \& Mart. (HRCB: Moraes 3465) \\
\hline \multirow[t]{3}{*}{ Ocotea Aubl. } & Ocotea nutans (Nees) Mez (SPF: Assis et al. 1244; HRCB: Moraes 3486) \\
\hline & Ocotea prolifera (Nees \& Mart.) Mez (SPF: Assis et al. 1245) \\
\hline & Ocotea puberula (Rich.) Nees (HRCB: Moraes \& Siqueira 3489) \\
\hline
\end{tabular}

Note. Classification based on Rohwer and Rudolph (2005).

relationships within the family. Molecular data indicate that the Cryptocarya group is sister to all other Lauraceae except Hypodaphnis (Rohwer 2000; Chanderbali et al. 2001; Rohwer and Rudolph 2005; Rohwer et al. 2014). The remaining taxa investigated belong in the core Lauraceae clade, in the tribe Cinnamomeae (Chanderbali et al. 2001; Rohwer and Rudolph 2005).

\section{Material and Methods}

Plants examined here with their herbaria references are listed in table 1 . All plants were collected growing in their natural habitats in Brazil. Flower organization and development were examined for all species and flower vasculature for Cryptocarya moschata and Ocotea prolifera. Our sampling strategy was partly driven by availability of these poorly known taxa, but it also allowed some systematic comparison. Most of the selected species (table 1) are included in the Ocotea complex, following the phylogenetic study of Chanderbali et al. (2001). Two (Aniba firmula and Licaria aff. guianensis) belong in the Licaria group. Ocotea prolifera is incertae sedis. Endlicheria paniculata, Nectandra nitidula, Nectandra psamophilla, Ocotea nutans, and Ocotea puberula are included in a subclade composed of the genera Endlicheria, Nectandra, Ocotea (dioecious species), Pleurothyrium, and Rhodostemonodaphne. In addition, we included C. moschata; although this species is phylogenetically distant from the Ocotea complex, it could show morphological similarities to that clade. Although some taxa are inevitably missing, the genera of the Ocotea complex sampled here provide a useful overview of floral morphology within the clade.

Flowers at different developmental stages were fixed in FAA and stored in $70 \%$ ethanol. For LM, they were embedded in Paraplast and serially sectioned at ca. $12 \mu \mathrm{m}$ thickness using a rotary microtome. Sections were mounted onto microscope slides, stained in safranin and Alcian blue, dehydrated through an ethanol series to $100 \%$ ethanol, transferred to Histoclear, and mounted in DPX mounting medium (distrene, with dibutyl phthalate and xylene). Slides were examined using a Leica DMLB photomicroscope fitted with a Zeiss Axiocam digital camera. For SEM examination, fixed inflorescences and flowers were carefully dissected in $70 \%$ ethanol and then dehydrated in an ethanol series to $100 \%$ ethanol. Then they were critical-point dried using a Bal-Tec 030 critical-point dryer, mounted onto pin stubs, coated with platinum using an Emitech K550 sputtercoater, and examined using a Hitachi cold field emission SEM S- 4700 at $2 \mathrm{kV}$.

\section{Results}

\section{Mature Flower Structure}

Descriptions apply to all species, except where stated. Features of the perianth and androecium are compared in table 2 and illustrated in figure 1 . Flowers have a distinct pedicel, and the receptacle is cup shaped (fig. $1 \mathrm{C}, 1 \mathrm{~K}$ ). The perianth consists of two alternating whorls of three tepals each, which are morphologically and anatomically similar to each other. The androecium consists of three whorls of fertile stamens: the first and third are located in the same sector as the outer tepals, and the second is located in the same sector as the inner tepals (fig. $1 A, 1 B, 1 D$ ). The stamens of the two outer whorls are inserted in almost a single series. Each stamen consists of a very short, broad filament (fig. $1 L$ ) and a basifixed anther with two pollen sacs and two introrse valves in Aniba, Endlicheria, and Licaria (fig. $1 B, 1 D, 1 E$ ); four pollen sacs and two introrse valves in Cryptocarya; and four introrse valves in Nectandra and Ocotea (fig. 1G). The two valves are almost apical in Aniba and Licaria (fig. $1 B, 1 E$ ) and lateral in Cryptocarya and Endlicheria (fig. 1C, 1D). In Nectandra, the four valves are arranged almost collaterally (fig. $1 F$ ), and in Ocotea, they are superimposed (fig. 1G). The stamens of the third (innermost) whorl differ from the outer stamens in possessing anthers with extrorse valves and a pair of basal appendages on the abaxial side of the filament (fig. $1 A, 1 C, 1 D, 1 F, 1 G$ ). At maturity, these appendages are quite conspicuous; in most species, they are ovoidal or square in shape (fig. $1 A, 1 C, 1 F-1 I, 1 L$ ). In 


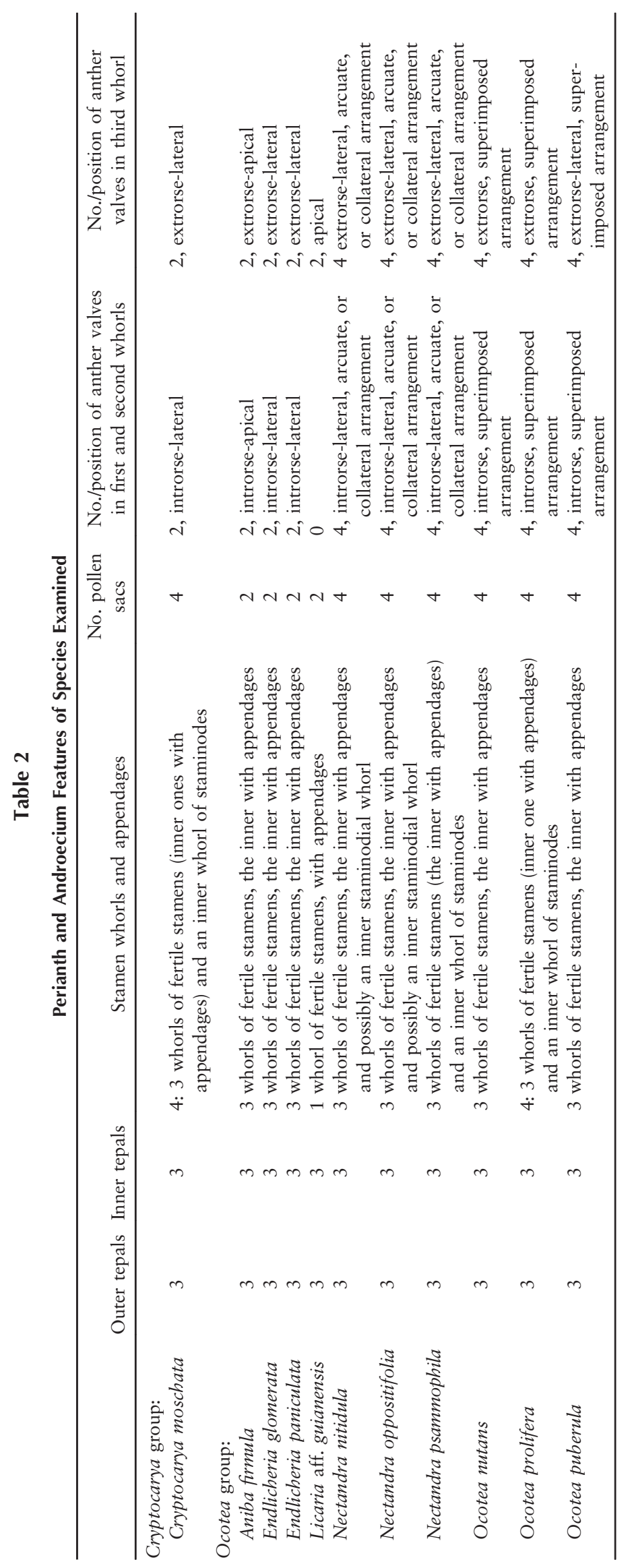

This content downloaded from 186.217.236.055 on June 24, 2019 09:47:00 AM 

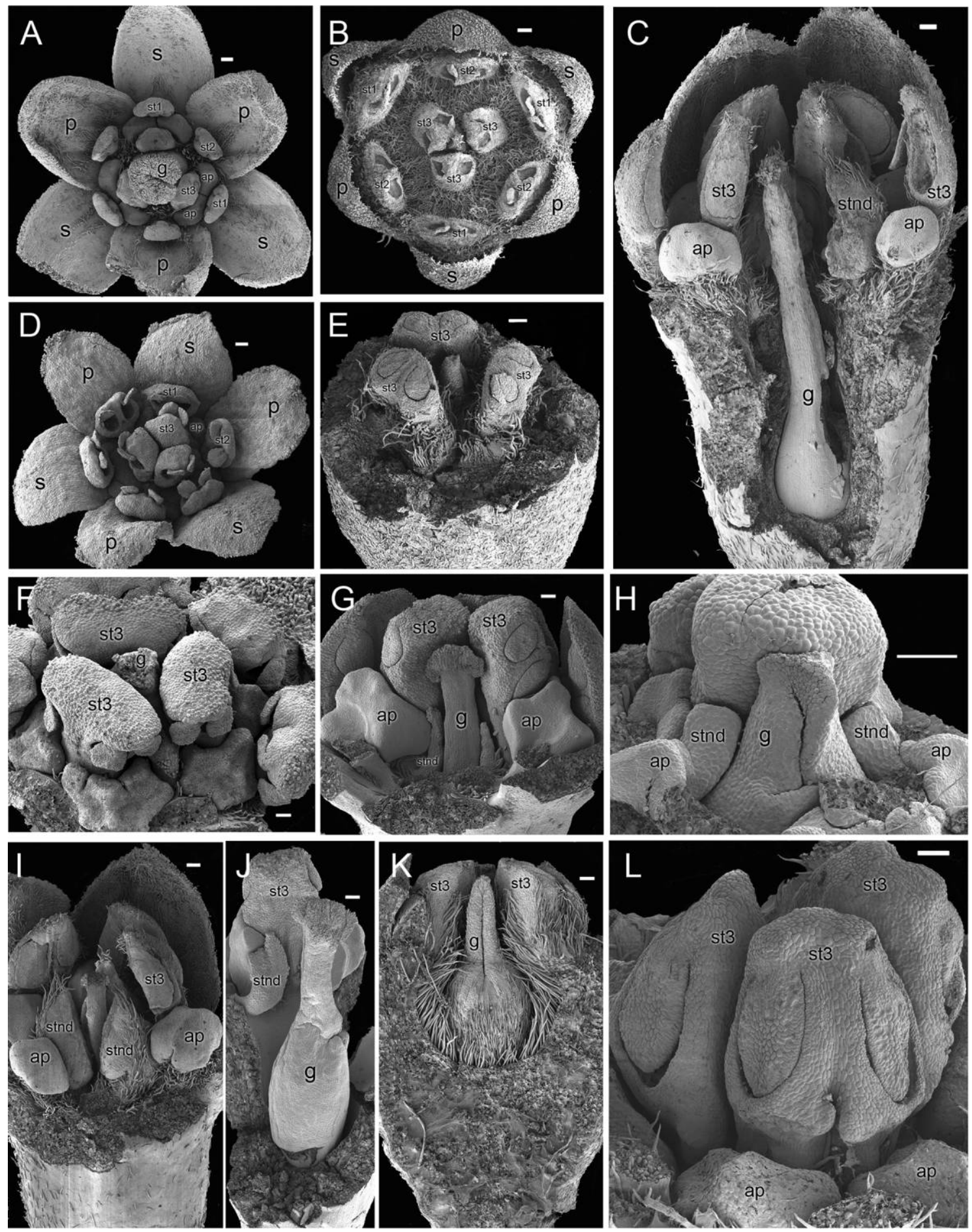

Fig. 1 Floral organography (SEM). A, Ocotea puberula (functionally female flower, so all androecial elements will be sterile); $B$, Aniba firmula; C, Cryptocarya moschata; D, Endlicheria glomerata (male flower); E, Licaria aff. guianensis; F, Nectandra psammophila; G, Ocotea prolifera; H, Nectandra psammophila; I, C. moschata; J, O. prolifera; K, Licaria aff. guianensis; L, Endlicheria paniculata (third androecial whorl). ap = appendage; $\mathrm{g}=$ gynoecium; $\mathrm{p}=$ inner tepal; $\mathrm{s}=$ outer tepal; st $1=$ outer androecial whorl, opposite outer tepals; st $2=$ androecial whorl opposite inner tepals; st $3=$ inner androecial whorl opposite s and st 1 whorls; stnd $=$ staminode. Scale bars $=100 \mu \mathrm{m}$. 
Cryptocarya moschata, Nectandra psammophila, and Ocotea prolifera, a fourth (innermost) androecial whorl of three staminodes lies in the same floral sector as the inner tepals and the second staminal whorl (fig. 1G-1I). In N. psammophila and O. prolifera, the staminodes are poorly developed and linear (fig. $1 G, 1 H$ ). In C. moschata, the staminodes are relatively pronounced, with a short stalk and a developed triangularacute tip (fig. 1I); they possess two enlarged fused regions that resemble glands; they are fused to a reduced filament and lack sporangia. In all species examined, the single ovary is ascidiate for ca. $50 \%$ of its length and plicate above this level and along the style (fig. $1 H, 1 J, 1 K$ ). The stigma is small, papillate, and slightly capitate (fig. $1 \mathrm{C}, 1 \mathrm{~J}$ ).

\section{Development}

Flower buds are protected by two opposite bracts (fig. $2 A$ ). The three outer tepal primordia differentiate more or less simultaneously; the inner tepal primordia are initiated immediately afterward (fig. 2B). The plastochron between the two tepal whorls is short, and the gaps between the outer tepal primordia are wide, making outer and inner tepals initiate
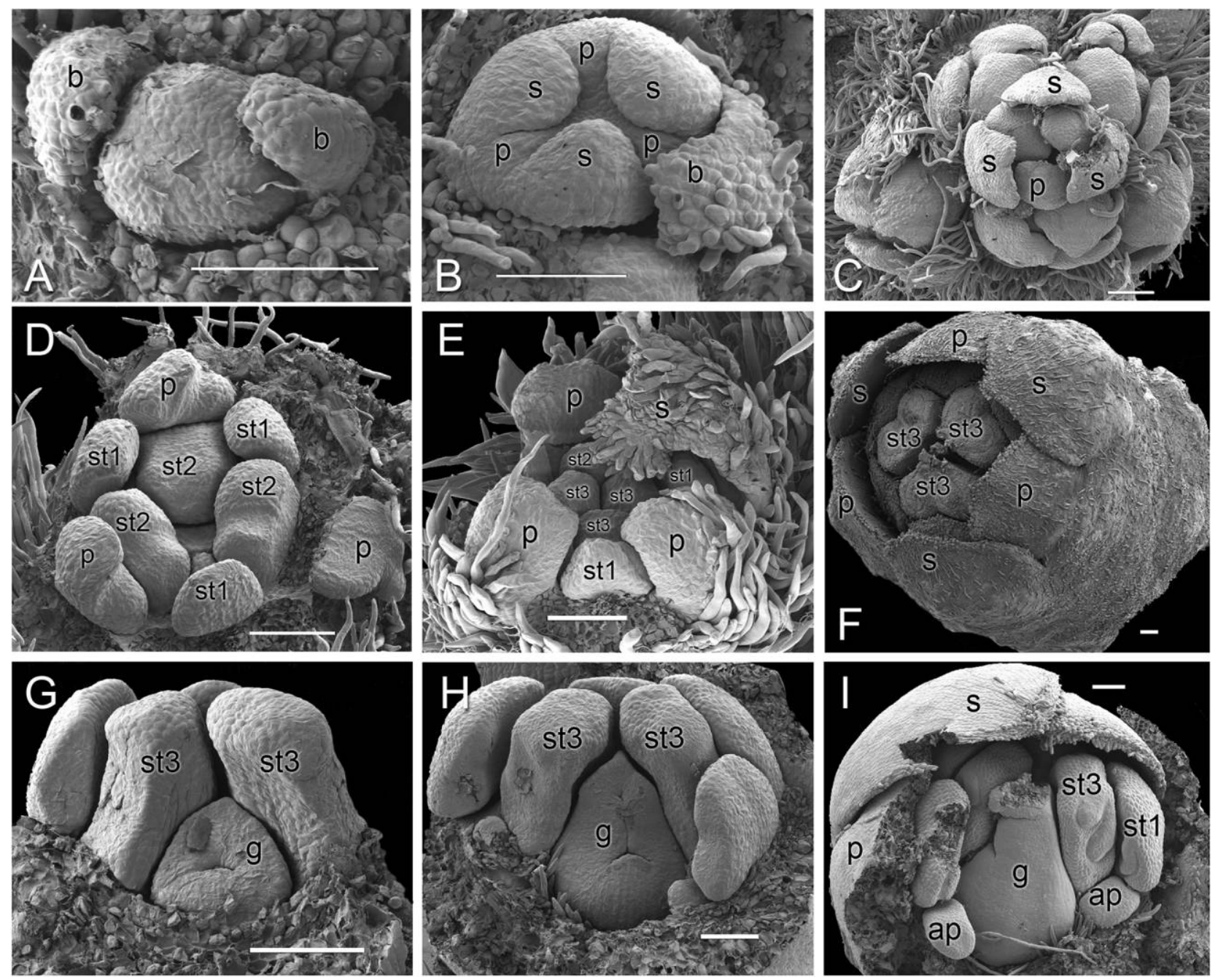

Fig. 2 Floral development (SEM). A, Ocotea prolifera; B-D, Aniba firmula; E, Endlicheria paniculata (male flower); F, Licaria aff. guianensis; $G-I$, Ocotea nutans (functionally female flower, so all androecial elements will be sterile). A, Flower bud protected by two bracts. $B$, Flower bud with three outer tepals and three inner tepal primordia. C, Perianth organs (outer and inner tepals) covering the bud center. $D$, Two outer stamen whorls initiating at the same time. E. Third stamen whorl (st3) differentiating later and opposite the outer tepals. F, Perianth organs (outer and inner tepals) covering the bud center. G, Staminodial primordia (st1 and st3) elongated and a single carpel primordium in the flower center. $H$, Staminodial primordia (st1-st3) with differentiating anther valves; the rim at the bottom of the carpel primordium corresponds with the cross zone that gives rise to the ascidiate region. I, Later stage; note basal appendages (ap) on the abaxial side of the inner staminodial whorl (st3). $\mathrm{b}=$ bract; $\mathrm{g}=$ gynoecium; $\mathrm{p}=$ inner tepal; $\mathrm{s}=$ outer tepal; st 1 and st $2=$ two outer androecial whorls; st $3=$ inner (third) androecial whorl. Scale bars $=100 \mu \mathrm{m}$. 
close together in almost a single series (fig. 2D). The tepals grow rapidly to cover the bud center (fig. $2 C, 2 F$ ).

The stamen primordia are distinguished from the tepal primordia by a longer plastochron and by a narrower cylindrical shape. The two outer stamen whorls are initiated almost simultaneously and are very similar to each other (fig. 2D). The third (innermost) whorl differentiates later (fig. 2E). The stamen primordia elongate, and the openings of their anthers develop inner-laterally in the two outer stamen whorls and laterally in the inner stamen whorl (fig. $2 \mathrm{G}, 2 \mathrm{H}$ ). A single primordium is then visible (fig. $2 G$ ), forming the gynoecium. The base of the primordium elongates axially; at the top of the primordium, one side grows more than the other, making a slope that becomes depressed; this depression outlines the future ovary cavity (fig. 2G, 2H). The rim at the bottom of the slope corresponds to the cross zone that later forms the ascidiate portion of the carpel or ovary (figs. $1 \mathrm{~J}, 1 \mathrm{~K}, 2 \mathrm{I}$ ). The lateral rims of the depression leading to the carpel apex bend inward and eventually fuse postgenitally, forming the style suture (fig. $1 K$ ).

At the same time as carpel curvature, the potential anther openings of the two outer stamen whorls change from a latrorse position to an introrse one, while those of the inner stamen whorl become extrorse (figs. $1 \mathrm{~B}, 1 \mathrm{D}, 2 \mathrm{H}, 2 \mathrm{I}$ ). After the carpel and anthers have differentiated, two appendages (outgrowths) are initiated at the base of each stamen of the third (inner) whorl (fig. $2 \mathrm{H}, 2 \mathrm{I}$ ). These appendages are abaxially positioned (fig. $1 \mathrm{~A}$, $1 F, 1 L)$ and ultimately resemble anthers in some species $(N$. psammophila, O. prolifera; fig. $1 F, 1 G$ ) and are globular in others (C. moschata; fig. 1C, 1I). We could not follow staminode differentiation in the three species bearing staminodes, as no young flowers of these species were available.

\section{Anatomy and Vasculature}

The small flowers of Lauraceae are densely covered with rigid trichomes, making it difficult to obtain serial cross sections; we could follow the vasculature of only $O$. prolifera and C. moschata, which both have four androecial whorls: three outer whorls of fertile stamens and an inner whorl of staminodes. Staminodes are poorly developed and linear in O. prolifera (fig. $1 G$ ) and relatively conspicuous with a triangular shape in C. moschata (fig. 1I).

In both species, there are four or five compound vascular bundles at the pedicel base (figs. $3 A, 4 A$ ) that form a ring of bundles at the flower base (figs. $3 B, 4 B$ ). The ring diameter enlarges at the flower receptacle (figs. $3 C, 4 C$ ). Just below the ovary, two bundles diverge internally from the ring to supply the gynoecium (fig. 3D).

In O. prolifera (fig. 3), the bundles that supply both inner and outer tepals diverge in six radii at the style level (fig. $3 E$ ). Each element receives three bundles. At the same level, a vascular bundle diverges internally from the bundle that will supply the middle of each inner tepal. The diverged trace will supply each of three staminodes of the inner androecial whorl (fig. 3E-3G). In each outer tepal, the three bundles diverge internally to vascularize the stamens of the inner fertile whorl (fig. $3 E-3 G$ ). Thus, three bundles enter the base of each stamen of the inner fertile whorl; one central bundle enters the filament, and the two lateral bundles supply the stamen appendages (fig. $3 F, 3 G$ ). At more distal floral levels, the vasculature inside the basal appendages ramifies (fig. $3 H$ ). At the level where the fertile inner whorl of stamens is just detached from the floral cup, the central bundles of both outer and inner tepals ramify internally (fig. 3F-3I). These six resulting bundles supply the two outer whorls of fertile stamens: the whorl opposite the outer tepals and the one opposite the inner tepals (fig. 3F-3I). In these two whorls, each stamen receives a single vascular bundle (fig. $3 G, 3 H$ ).

In C. moschata (as in O. prolifera), the bundles supplying the inner and outer tepals and associated stamens diverge at the same level (fig. 4D). Each tepal receives three vascular bundles, though here the lateral bundles of adjoining elements are merged (fig. 4D, arrows). At the style level, three inner bundle groups located opposite the inner tepals, each composed of three vascular bundles (fig. $4 E$ ), supply the innermost (staminodial) androecial whorl (fig. 4F-4I). In each group, the central bundle remains on the dorsal side of the staminode (fig. $4 H$ ) while the lateral ones ramify to supply the enlarged lateral regions (fig. $4 \mathrm{H}$, arrows). The central bundle of each group diverges from the bundle that will supply the center of the inner tepals (fig. 4D, 4E), and the lateral bundles come from the merged tepal bundles of the floral cup (fig. $4 D, 4 E$, arrows). Still at the style level, three inner bundles (fig. $4 E$ ) that diverge from the corresponding central outer tepal bundle supply the stamens of the third fertile androecial whorl (fig. 4F). At the level of figure $4 F$, each stamen bundle (st 3 ) is flanked by two others (arrows) that diverge from the lateral merged bundles of adjoining tepals and enter the lateral appendages via a short pedicel (fig. 4H), ramifying inside the appendage (fig. 4I). Thus, the lateral bundles of the staminode and those supplying the stamen appendages of the inner androecial whorl have a common origin in the floral cup. At the level of figure $4 \mathrm{H}$, the central bundle of both outer and inner tepals branches internally to supply the two outer whorls of fertile stamens: the whorl opposite the outer tepals (fig. 4I, 4J) and the one opposite the inner tepals (fig. 4I, $4 J)$. In these two whorls, each stamen receives a single vascular bundle.

\section{Discussion}

All the flowers examined here are typical of Lauraceae in that they are small (less than $1 \mathrm{~cm}$ in diameter), mostly bisexual (or unisexual in Ocotea nutans and Ocotea puberula), and possess two perianth whorls, multiple androecium whorls, and a single carpel. The cup-shaped receptacle represents a synapomorphy of Laurales that has been lost in some taxa (Renner 1999; Renner and Chanderbali 2000; Chanderbali et al. 2001). There are many exceptions to the typical Lauraceae flower plan; members of the tribe Laureae and the clade Endlicheria, Ocotea pro parte, and Rhodostemonodaphne (sensu Chanderbali et al. 2001) are dioecious, and the anthers of the inner whorl open introrsely, possibly because the pistillode is either reduced or absent. Other features such as a fourth (staminodial) androecial whorl, which are common in some taxa (i.e., the Persea group of Chanderbali et al. 2001), also occur in some species of more distantly related genera (e.g., Cryptocarya from Chanderbali et al.'s Cryptocarya group and Ocotea and Nectandra from their Ocotea complex). Assuming the existing molecular topology of Lauraceae is correct (Chanderbali et al. 2001), several characters are probably homoplasious within the family, including an innermost staminode whorl and the occasional occurrence 


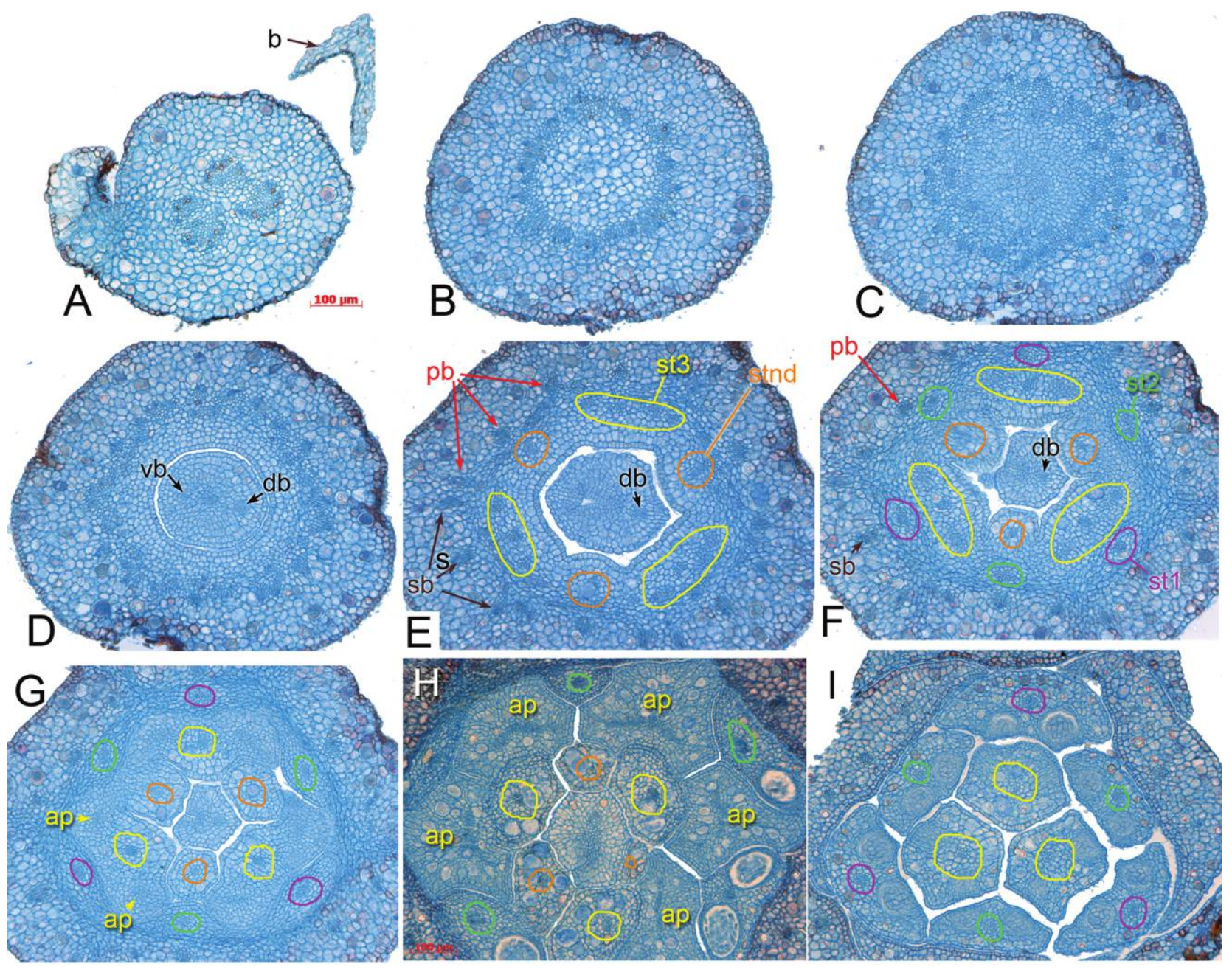

Fig. 3 Ocotea prolifera, serial sections through a single flower at the megasporocyte stage, showing anatomy and vasculature (LM). A, Pedicel base. $B$, Median region of pedicel. $C$, Receptacle. D, Ovary base; note that two bundles (dorsal and ventral) supply the gynoecium. The surrounding floral cup has a ring of vasculature. E, Upper region of ovary; note the divergence of the bundles of the outer and inner tepals. In each outer tepal, the three bundles diverge to supply the inner stamen whorl (st3). In each inner tepal, the median bundle diverges to supply the innermost staminode whorl (stnd). $F-H$, Upper flower levels. The lateral bundles of each inner stamen (st3) supply their abaxial appendages, and the central one enters the filament. The median bundles of both outer tepal (arrowhead) and inner tepals (arrow) diverge to supply the two outer stamen whorls. I, Stamen level, with three stamen whorls, two opposite the outer tepals (st 1 and st3) and one opposite the inner tepals (st2). ap = appendage; $b=$ bract; db = dorsal bundle (of gynoecium); $\mathrm{pb}=$ inner tepal bundle (in red); $\mathrm{s}=$ outer tepal; $\mathrm{sb}=$ outer tepal bundle; st1 (magenta) = vascular bundles of outer stamen whorl; st2 (green) = bundles of stamen whorl opposite inner tepals; st3 (yellow) = bundles of inner stamen (with appendages); stnd (brown) = bundles of staminode; $\mathrm{vb}=$ ventral bundle (of gynoecium). Scale bars $=100 \mu \mathrm{m}$.

of three or more perianth whorls in few genera, such as Litsea and Umbellularia (Kasapligil 1951; Rohwer 1993, 1994). In any case, different types of morphological data provide conflicting phylogenetic signals; cuticular characters agree with the molecular topology of the various clades of the Ocotea complex rather than with species groupings that follow the traditional generic concepts (Nishida and van der Werff 2007).

\section{Perianth}

Despite the inevitably limited availability of plants, our investigation represents probably the most extensive comparative anatomical and developmental study of flowers of differ- ent genera of Lauraceae. An important benchmark is Buzgo et al.'s (2007) detailed study of Persea americana, a species that belongs in a different tribe of core Lauraceae from our study group (table 1) but resembles them in several respects. For example, in both our plants and $P$. americana, the perianth organs are initiated in rapid succession and almost in a single whorl rather than in a spiral.

In the species examined here, each perianth organ (outer and inner tepals) receives three vascular bundles, although the lateral bundles of adjoining perianth organs are basally merged in the floral cup in Cryptocarya moschata. Similarly, in most other Lauraceae, the perianth organs are each vascularized by three or more vascular bundles (Kasapligil 1951; 


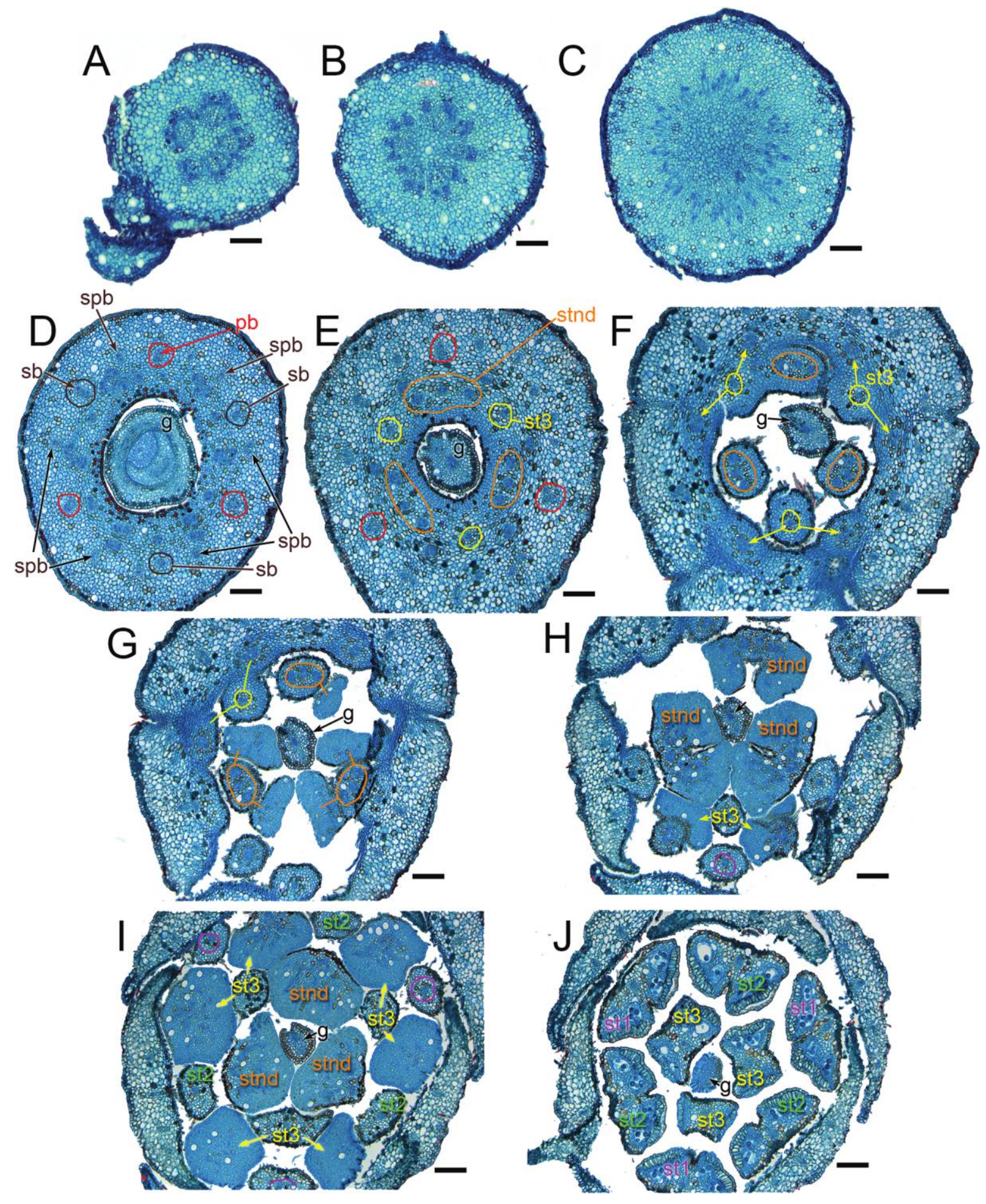

Fig. 4 Cryptocarya moschata, serial sections through a single flower showing anatomy (LM). A, Pedicel base. $B$, Median region of pedicel. $C$, Receptacle. $D$, Close to ovary base; note divergence of outer tepal and inner tepal bundles. Each tepal receives three bundles, but at this level the lateral bundles of adjoining tepals are fused. E, Middle region of style. F-I, Distal flower levels. Each inner stamen bundle (st3, yellow) is flanked by two bundles ( $F, G$, arrows) that supply the abaxial stamen appendages. From the staminode bundles (circled in $E$ ), the median one supplies its dorsal side and the lateral ones ramify to supply its enlarged parts. $\mathrm{g}=$ gynoecium; $\mathrm{pb}$ (in red) $=$ inner tepal bundle; $\mathrm{sb}=$ outer tepal bundle; $\mathrm{spb}=$ vascular bundle that will diverge to supply lateral regions of inner and outer tepals; st1 (magenta) $=$ outer stamen whorl (vascular bundles ringed in $H, I$ ); st2 (green) = stamen whorl opposite inner tepals; st3 (yellow) = inner stamen whorl (bundles ringed in $E-G$, with arrows to appendages); stnd (brown) $=$ staminode (vascular bundles ringed in $E-G$ ). Scale bars $=100 \mu \mathrm{m}$. 
Sastri 1965). The fact that both perianth whorls in most Lauraceae possess similar vasculature with at least three bundles is consistent with their interpretation as bracteotepals (reviewed in Ronse De Craene 2008; Warner et al. 2009), as suggested by other authors (e.g., Sastri 1965), contra Chanderbali et al.'s (2006) interpretation as androtepals. One exception is Umbellularia californica, in which the two perianth whorls are morphologically similar but differ in vasculature: the outer tepals receive three bundles each (sometimes four to five), and the inner tepals each receive a single bundle (Kasapligil 1951). Another rare exception is Cassytha, in which the inner tepals possess three bundles each and the outer ones only one (Sastri 1952, 1965), a highly unusual condition that is the reverse of the usual pattern observed for angiosperms (especially eudicots), in which outer tepals typically have three to five bundles and inner tepals only one. This exceptional pattern probably reflects extreme reduction of the outer tepals in the parasitic genus Cassytha, which is nested within a phylogenetically derived clade of Lauraceae, and possesses several other autapomorphic features (Heo et al. 1998; Rohwer and Rudolph 2005).

\section{Androecium}

Stamen appendages are common in Lauraceae, as in some other Laurales (e.g., Monimiaceae, Hernandiaceae, Gomortegaceae; Sastri 1965; Endress and Hufford 1989). In Lauraceae, stamen appendages are normally restricted to the third (innermost) fertile stamen whorl, though a few (mostly atypical or teratological) exceptions have been reported (e.g., in P. americana; Buzgo et al. 2007). They are often conspicuous and resemble anthers. Both stamen appendages and staminodes are densely vascularized and possess many oil cells, suggesting that they could have a secretory role, perhaps as nectaries, as in many other Lauraceae (Kasapligil 1951; Sastri 1965; Buzgo et al. 2007; Rohwer 2009). In our plants, the stamen appendages differentiate late in flower development.

The question of whether these appendages are homologous with stamens, anthers, or modified outgrowths (branches or stipules) has been debated in detail. Sastri (1965) discussed whether they could represent highly reduced stamen fascicles and cited as evidence Kasapligil's (1951) observation that the inner stamens of Umbellularia possess up to five vascular bundles. This latter observation is supported by ours: the inner stamens are each supplied by three bundles, of which the middle bundle supplies the stamen and the two laterals enter the appendages. The absence of transitional forms (i.e., from stamens to appendages) in either living or fossil taxa does not necessarily contradict a possible stamen homology, as there could have been a saltational transformation. However, the late initiation of the appendages argues against this conclusion, since stamens are typically initiated early in ontogeny. Furthermore, the presence of a pair of appendages on the third whorl is a plesiomorphic condition within Lauraceae. The presence of a pair of appendages on all androecial whorls in Chlorocardium and Urbanodendron (Rohwer 1993) probably represents a homoplasious condition for these genera and hence a further potential obstacle for homologizing stamens and appendages.

In most Lauraceae, the two outer stamen whorls possess introrse anthers, and the third whorl is extrorse (e.g., Rohwer
2016). This unusual condition, which is possibly related to male and female phases (Rohwer 2009), was typical of plants examined here, though all anthers were latrorse at early stages; both introrse and extrorse conditions were achieved by subsequent differential growth (fig. 2H, 2I), as Buzgo et al. (2007) also reported in $P$. americana. The stamens of the two outer whorls are each supplied by a single vascular bundle that diverges from the bundle of either the median inner tepal or the outer tepal, according to the stamen position.

In three species examined here (C. moschata, Nectandra psammophila, and Ocotea prolifera), the innermost (fourth) stamen whorl is staminodial. Staminodes of Ocotea and Nectandra are linear and possess a single vascular bundle, whereas those of Cryptocarya are conspicuous and stamen-like, resembling staminodes of $P$. americana (see fig. $3 J$ in Buzgo et al. 2007), though an acute apex resembling a style and a rudimentary stigma, as reported for $P$. americana, was not observed here. Each staminode in Cryptocarya is supplied by three vascular bundles, as in the fertile stamens of the third inner whorl. However, in the stamens each bundle enters independently, the central bundle supplying the filament and the laterals the appendages, whereas in the staminodes, the three bundles enter together, the two laterals branching to supply the broad regions. The inner stamens are fertile with an elongated filament bearing basal glands and differentiated sporangia; the staminodes possess two enlarged fused regions that resemble glands. Kasapligil (1951) hypothesized that an increase in stamen number could have coincided with loss of appendages in the outer fertile stamens and a shift in anther dehiscence and loss of lateral vasculature in the inner staminodes. Buzgo et al. (2007) proposed a transition from tepals to staminodes for Persea. Our data alone cannot resolve the morphological transitions within the androecium of Lauraceae, but they confirm the similarity between the vasculature of the staminodes and the inner fertile stamens, suggesting that they are "true staminodes" derived from stamens (Ronse De Craene and Smets 2001). A floral developmental-genetic study of $P$. americana found that transcriptional programs of ABC-function floral MADS-box genes are expressed in broad domains that overlap across adjacent whorls, supporting the "fading borders" model for organ identity determination in flowers of early-divergent angiosperms (Chanderbali et al. 2009).

\section{Gynoecium}

Divergent views were expressed among early morphologists regarding the number of carpels that form the gynoecium in Lauraceae, from a single carpel to three carpels (reviewed in Kasapligil 1951). However, most research, including studies of carpel initiation, indicates normal monomery rather than pseudomonomery in Lauraceae and other Laurales (Endress 1972; Endress and Igersheim 1997). The gynoecium originates terminally on the floral shoot apical meristem (SAM; Endress 1994; Buzgo et al. 2007). This conclusion corresponds with our observations: the single carpel is initiated as a single primordium whose base elongates axially. The carpel primordium takes up the center of the floral SAM, as reported for other Lauraceae (Endress 1994; Buzgo et al. 2007). Consistent with an ascidiate carpel, the cross zone gives rise to the ovule and a secondary outgrowth overtops it, forming the adaxial stigma margin. 
Two vascular bundles supply the single carpel, as also reported for Laurus nobilis (Kasapligil 1951), Litsea sebifera, and three species of Cassytha (Sastri 1965), though in Cinnamomum the gynoecium can be variously vascularized by four, six, or many bundles (Sastri 1952, 1958, 1965) and in Persea by six (Reece 1939). Sastri (1965) considered the two-trace condition a derived feature in Lauraceae, as both Cynnamomum and Persea were then placed in primitive tribes. However, recent molecular analyses make this conclusion appear less likely (e.g., Rohwer and Rudolph 2005).

\section{Conclusions}

Detailed studies of floral development in basal angiosperms have highlighted similarities between stamens and carpels and between perianth and androecium organs. For Persea americana, Buzgo et al. (2007) suggested a correlation between the constricted carpel base (stipe) and the stamen filament (including the appendage stalks and the filament-like base of the staminodes) and with the base of tepals. However, we found little evidence of morphological transitions among the different flower whorls of Lauraceae. The presence of three vascular bundles at the bases of both outer and inner tepals supports their potential homology as bracteotepals. The staminodia of the fourth androecial whorl are clearly derived from stamens, which typically have a single vascular bundle. However, the vasculature of both the third and fourth androecial whorls differs from that of the two outer androecial whorls in having three bundles at their bases, the two lateral bundles supplying the appendages (on the stamens of the third whorl) and the glands (on the staminodes of the fourth whorl). Thus, it remains possible that both the appendages and the glands could represent staminodial homologues. Comparisons with fossil Lauraceae (e.g., von Balthazar et al. 2007; Atkinson et al. 2015) have indicated numerous androecial transitions during the long evolutionary history of this ancient plant family. A better understanding of floral evolution in Lauraceae will depend on further comparative analyses of additional taxa and a more detailed phylogeny both within the family Lauraceae and among its broader relationships.

\section{Acknowledgments}

We are grateful to two anonymous reviewers for their helpful and constructive comments on the manuscript. Financial support was provided by CNPq for M. G. Sajo; by CAPES, CNPq, and PLRM for P. Moraes; and by FAPEMIG (APQ01225-13) and FAPESP (2010/08382-1) for L. C. S. Assis.

\section{Literature Cited}

Atkinson BA, RA Stockey, GW Rothwell, RA Mindell, MJ Bolton 2015 Lauraceous flowers from the Eocene of Vancouver Island: Tinaflora beardiae gen. et sp. nov. (Lauraceae). Int I Plant Sci 176: 567-585.

Buzgo M, AS Chanderbali, S Kim, Z Zheng, DG Oppenheimer, P Soltis, D Soltis 2007 Floral developmental morphology of Persea americana (avocado, Lauraceae): the oddities of male organ identity. Int I Plant Sci 168:261-284.

Chanderbali AS, VA Albert, J Leebens-Mack, NS Altman, DE Soltis, PS Soltis 2009 Transcriptional signatures of ancient floral developmental genetics in avocado (Persea americana; Lauraceae). Proc Natl Acad Sci USA 106:8929-8934.

Chanderbali AS, S Kim, M Buzgo, Z Zheng, DG Oppenheimer, DS Soltis, PS Soltis 2006 Genetic footprints of stamen ancestors guide perianth evolution in Persea (Lauraceae). Int I Plant Sci 167:10751089.

Chanderbali AS, SS Renner, H van der Werff 2001 Phylogeny and historical biogeography of Lauraceae: evidence from the chloroplast and nuclear genomes. Ann Mo Bot Gard 88:104-134.

Doyle JA, PK Endress 2000 Morphological phylogenetic analysis of basal angiosperms: comparison and combination with molecular data. Int I Plant Sci 161(suppl):S121-S153.

Drinnan A, P Crane, EM Friis, K Pedersen 1990 Lauraceous flowers from the Potomac Group (mid-Cretaceous) of eastern North America. Bot Gaz 151:370-384.

Eklund H 2000 Lauraceous flowers from the Late Cretaceous of North Carolina, USA. Bot I Linn Soc 132:397-428.

Eklund H, J Kvacek 1998 Lauraceous inflorescences and flowers from the Cenomanian of Bohemia (Czech Republic, Central Europe). Int I Plant Sci 159:668-686.

Endress PK 1972 Zur vergleichenden Entwicklungsmorphologie, Embryologie und Systematik bei Laurales. Bot Jahrb Syst 92:331428.

1994 Diversity and evolutionary biology of tropical flowers. Cambridge University Press, Cambridge.
Endress PK, LD Hufford 1989 The diversity of stamen structures and dehiscence patterns among Magnoliidae. Bot I Linn Soc 100:45-85.

Endress PK, A Igersheim 1997 Gynoecium diversity and systematics of the Laurales. Bot I Linn Soc 125:93-168.

Heo K, H van der Werff, H Tobe 1998 Embryology and relationships of Lauraceae (Laurales). Bot I Linn Soc 126:295-322.

Kasapligil B 1951 Morphological and ontogenetic studies of Umbellularia californica Nutt and Laurus nobilis L. Univ Calif Publ Bot 25: 115-239.

Nishida S, H van der Werff 2007 Are cuticular characters useful in solving generic relationships of problematic species of Lauraceae? Taxon 56:1229-1237.

Reece PC 1939 The floral anatomy of the avocado. Am I Bot 36: 429-433.

Renner SS 1999 Circumscription and phylogeny of the Laurales: evidence from molecular and morphological data. Am I Bot 86:13011315.

2004 Variation in diversity among Laurales, Early Cretaceous to present. K Dan Vidensk Selsk Biol Skr 55:441-458.

Renner SS, AS Chanderbali 2000 What is the relationship among Hernandiaceae, Lauraceae, and Monimiaceae, and why is this question so difficult to answer? Int I Plant Sci 161(suppl):S109-S119.

Rohwer JG 1993 Lauraceae. Pages 426-437 in K Kubitzki, JG Rohwer, V Bittrich, eds. The families and genera of flowering plants. Springer, Berlin.

1994 A note on the evolution of stamens in the Laurales with emphasis on the Lauraceae. Bot Acta 107:103-110.

2000 Towards a phylogenetic classification of the Lauraceae: evidence from matK sequences. Syst Bot 25:60-71.

2009 The timing of nectar secretion in staminal and staminodial glands in Lauraceae. Plant Biol 11:490-492. 2016.

Rohwer JG, PLR de Moraes, B Rudolph, H van der Werff 2014 A phylogenetic analysis of the Cryptocarya group (Lauraceae), and 
relationships of Dablgrenodendron, Sinopora, Triadodaphne, and Yasunia. Phvtotaxa 158:111-132.

Rohwer JG, B Rudolph 2005 Jumping genera: the phylogenetic positions of Cassytha, Hypodaphnis and Neocinnamomum (Lauraceae) based on different analyses of $\operatorname{trnK}$ intron sequences. Ann Mo Bot Gard 92:153-178.

Ronse De Craene LP 2008 Homology and evolution of petals in the core eudicots. Syst Bot 33:301-325.

Ronse De Craene LP, EF Smets 2001 Staminodes: their morphological and evolutionary significance. Bot Rev 67:351-402.

Sastri RLN 1952 Studies in the Lauraceae. I. Floral anatomy of Cinnamomum iners Reinw. and Cassytha filiformis L. J Indian Bot Soc 31:240-246.
1958 Studies in the Lauraceae. II. Embryology of Cinnamomum and Litsea. J Indian Bot Soc 37:266-278.

1965 Studies in the Lauraceae. V. Comparative morphology of the flower. Ann Bot 29:39-44.

von Balthazar M, KR Pedersen, PR Crane, M Stampanoni, EM Friis 2007 Potomacanthus lobatus gen. et sp. nov., a new flower of probable Lauraceae from the Early Cretaceous (Early to Middle Albian) of eastern North America. Am I Bot 96:2041-2053.

Warner KA, PJ Rudall, MW Frohlich 2009 Environmental control of sepalness and petalness in perianth organs of waterlilies - a new mosaic theory on the evolutionary origin of a differentiated perianth. IExp Bot 60:3559-3574. 